\title{
Correction to: Self-care and remote care during pregnancy: a new paradigm?
}

\author{
A. Metin Gülmezoglu', Anne Ammerdorffer ${ }^{1 *}$, Manjulaa Narasimhan², Alyce N. Wilson ${ }^{3}$, Joshua P. Vogel', \\ Lale Say ${ }^{2}$ and Özge Tunçalp ${ }^{2}$
}

Correction to: Health Res Policy Sys 18, 107 (2020)

https://doi.org/10.1186/s12961-020-00627-4

It was highlighted that the original article [1] contained a numerical error on the second page of the article. This Correction article shows the correct and incorrect sentence. The original article has been updated.

\section{Correct sentence}

It should be noted that the intervention was delivered to a relatively affluent population in the United States where standard care included 12 to 14 in-person contact visits - much higher than the 8 contacts recommended by WHO.

\section{Incorrect sentence}

It should be noted that the intervention was delivered to a relatively affluent population in the United States where standard care included 12 to 14 in-person contact visits - much higher than the 88 contacts recommended by WHO.

\section{Author details}

${ }^{1}$ Concept Foundation, Geneva, Switzerland. ${ }^{2}$ UNDP/UNFPA/UNICEF/WHO/ World Bank Special Programme of Research, Development and Research Training in Human Reproduction, Department of Sexual and Reproductive Health and Research, World Health Organization, Geneva, Switzerland. ${ }^{3}$ Maternal, Child and Adolescent Health Program, Burnet Institute, Melbourne, Australia.

Published online: 12 October 2020

\section{Reference}

1. Gülmezoglu, et al. Self-care and remote care during pregnancy: a new paradigm? Health Res Policy Sys. 2020;18:107 https://doi.org/10.1186/ s12961-020-00627-4.

*Correspondence: a.ammerdorffer@conceptfoundation.org

${ }^{1}$ Concept Foundation, Geneva, Switzerland

Full list of author information is available at the end of the article

(C) The Author(s). 2020 Open Access This article is licensed under a Creative Commons Attribution 4.0 International License, which permits use, sharing, adaptation, distribution and reproduction in any medium or format, as long as you give appropriate credit to the original author(s) and the source, provide a link to the Creative Commons licence, and indicate if changes were made. The images or other third party material in this article are included in the article's Creative Commons licence, unless indicated otherwise in a credit line to the material. If material is not included in the article's Creative Commons licence and your intended use is not permitted by statutory regulation or exceeds the permitted use, you will need to obtain permission directly from the copyright holder. To view a copy of this licence, visit http://creativecommons.org/licenses/by/4.0/. The Creative Commons Public Domain Dedication waiver (http://creativecommons.org/publicdomain/zero/1.0/) applies to the data made available in this article, unless otherwise stated in a credit line to the data. 